\title{
TexPrince, a Midseason, Medium-chill Peach
}

David H. Byrne and Terry A. Bacon ${ }^{1}$

Department of Horticultural Sciences, Texas A\&M University, College Station, TX 77843-2133

Additional index words. fruit breeding, medium chilling, Prunus persica

Abstract. 'TexPrince' is being released by Texas A\&M University to provide a medium chilling, commercially acceptable peach that ripens after 'Texstar' and with or a few days after 'Juneprince' and 'TexRoyal'. This large, freestone, attractive, yellow-flesh peach ripens early June in the medium chill zones of the United States. 'TexPrince' is a replacement for 'Juneprince' where 'Juneprince' fruit inconsistently due to problems with insufficient chilling.

Fig. 1. Pedigree of TexPrince.

\section{Origin}

'TexPrince' peach [Prunus persica (Bastch) L.] originated in the Stone Fruit Breeding Program of the Department of Horticultural Sciences at Texas A\&M University, located in College Station, Texas. The cross was made in 1989 with pollen from 'Flordaking', a variety released by the University of Florida (Andrews et al., 1979) on a tree of the selection P60-12 ('Firebrite' $x$ 'Sunfre') at the USDA, ARS Horticulture Fruit Crops Research Laboratory with the cooperation of Dr. David W. Ramming (Fig. 1).

The seedlings were planted in the highdensity fruiting nursery at College Station in 1990. 'TexPrince' was selected as TX3592-7 in 1992 for its midseason maturity, large fruit size, good productivity, yellow ground color, round shape, high red overcolor, and excellent firmness. It was propagated asexually by budding onto peach rootstock and test plantings were established in Texas, California, and southern Spain.

\section{Description}

'TexPrince' was selected for adaptation in the medium chill zone of south central Texas. It has been fruited in three sites (Yoakum, Floresville and College Station) in Texas, in California (Clovis), and in southern Spain (Sevilla). The peach selection is adapted in areas where 'Texstar' (Byrne and Kamas, 1984) can be grown commercially and fruits more consistently than 'Juneprince'. In two low chill years ( $<700$ chill units), 'TexPrince' and 'Texstar' had full crops whereas 'Juneprince' had $<50 \%$ of a full crop. This medium chill region generally receives at least 550 chilling units. The mean temperature of the coldest month in these areas is between 13.1 to 11.0 ${ }^{\circ} \mathrm{C}$. It can also be grown in higher chill areas in the absence of temperatures below $-1.7^{\circ} \mathrm{C}$

Received for publication 14 Feb. 2003. Accepted for publication 8 July 2003. Research conducted by the Department of Horticultural Sciences, College Station, Texas.

${ }^{1}$ Stone fruit breeder, Sun World International, Inc., 16350 Driver Rd., Bakersfield, CA 93380-0298.

HortScience Vol. 39(3) June 2004

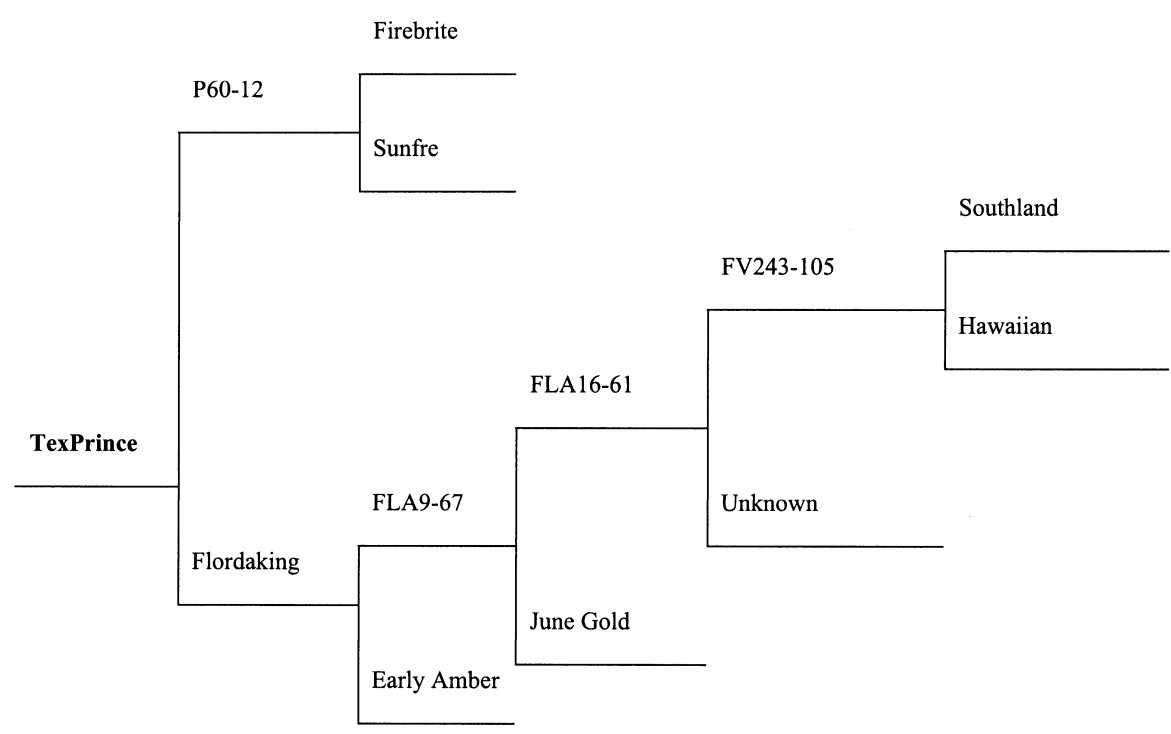

during flowering and fruit development. During the evaluation of 'TexPrince' the chilling received at College Station averaged 750 chilling units, but ranged from 545 to 1088 chilling units.

The tree of 'TexPrince' is vigorous with a semi-spreading growth habit, as are trees of 'Flordaking' and 'Texstar'. Based on field observations, 'TexPrince' has moderate resistance to bacterial leaf spot [Xanthomonas pruni (E.F. Smith) Dows.] as does 'Flordaking' and 'Texstar'. The moderately large leaves are lanceolate with acute bases, sharply acute apices, reniform glands and crenate margins.

'TexPrince' blooms 6 to $8 \mathrm{~d}$ after 'Flordaking' and $\approx 4 \mathrm{~d}$ before 'Texstar'. Flowers are non-showy with a diameter of 31 to $35 \mathrm{~mm}$ and petal length of $12 \mathrm{~mm}$. The five petals are light pink with a darker pink center vein. Sepals are reddish brown with green. Young anthers are yellow orange with a red-purple edge changing to a greyed-orange with a black edge as they age. Anthers are on filaments (12 $\mathrm{mm}$ in length) that are slightly shorter than the style (average length $13 \mathrm{~mm}$ ). Initially filaments are white, turning dark pink with purple with age. Pollen is yellow and abundant. The tree is self-fertile.

Trees of 'TexPrince' bear crops of midseason peaches that are firm and large for the season. The colors are described using the Royal Horticultural Society Colour Chart (Anonymous, 1995). Fruits are round to ovate, have a yellow ground color (20B to $22 \mathrm{~A}$ ), $60-80 \%$ red overcolor (43C to $46 \mathrm{~A}$ ), yellow melting flesh (15C to $20 \mathrm{C}$ ) with some red speckling and are freestone. 'TexPrince' fruit are as attractive as 'Juneprince' and 'TexRoyal' and more attractive than 'Texstar' or 'La Feliciana' (Table 1). The fruit flesh does not brown readily and there is no tendency to develop split or shattered pits during the final stage of fruit swelling. Stones are medium in size with an average dimensions of $32.4 \mathrm{~mm}$ in length, 20.8 $\mathrm{mm}$ in width, and $18.1 \mathrm{~mm}$ in height.

Fruit quality of 'TexPrince' is equal to that of the other major cultivars (Table 1). Fruit ripen about 14 days after 'Texstar', and with or a few days after 'Juneprince' (Okie and Reilly, 1987) and 'TexRoyal' (Byrne and Bacon, 1990), in the medium chill stone fruit production zone of Texas (Table 1).

\section{Availability}

A plant patent has been applied for and budwood can be acquired under a license agreement with the Texas Agricultural Experiment Station. 


\section{Cultivar and Germplasm Releases}

Table 1. Fruiting characteristics of 'TexPrince' compared to four medium-chill peach cultivars at College Station, Texas (1997-2001).

\begin{tabular}{|c|c|c|c|c|c|c|c|c|c|c|c|c|c|}
\hline Name & $\begin{array}{c}\text { Full } \\
\text { bloom }\end{array}$ & $\begin{array}{l}\text { FDP } \\
\left({ }^{2}\right)^{2}\end{array}$ & $\begin{array}{l}\text { Ripe } \\
\text { date }^{z}\end{array}$ & Crop $^{y}$ & $\operatorname{Size}^{\mathrm{x}}$ & Firm $^{w}$ & Blush $^{w}$ & Shape $^{w}$ & Tip $^{w}$ & $\begin{array}{l}\text { Ground } \\
\text { color }^{w}\end{array}$ & $\begin{array}{l}\text { Red in } \\
\text { flesh }^{v}\end{array}$ & Appearance w & Tastew \\
\hline Texstar & Feb 27 bc & $84 \mathrm{de}$ & May $23 \mathrm{c}$ & 5.4 & $4.7 \mathrm{~b}$ & $6.7 \mathrm{bc}$ & $5.4 \mathrm{~b}$ & $5.4 \mathrm{c}$ & $5.1 \mathrm{c}$ & $6.1 \mathrm{bc}$ & 0.2 & $5.6 \mathrm{c}$ & 6.7 \\
\hline TexPrince & Feb $23 \mathrm{c}$ & $102 \mathrm{~b}$ & June $7 \mathrm{~b}$ & 4.7 & $5.9 \mathrm{a}$ & $6.9 \mathrm{ab}$ & $7.2 \mathrm{a}$ & $7.4 \mathrm{a}$ & $7.6 \mathrm{ab}$ & $6.1 \mathrm{bc}$ & 1.5 & $7.1 \mathrm{a}$ & 6.8 \\
\hline TexRoyal & Mar 6 ab & $92 \mathrm{c}$ & June $6 \mathrm{~b}$ & 4.3 & $5.4 \mathrm{ab}$ & $6.6 \mathrm{bc}$ & $7.2 \mathrm{a}$ & $7.4 \mathrm{a}$ & $7.4 \mathrm{ab}$ & $6.0 \mathrm{bc}$ & 1.3 & $7.0 \mathrm{a}$ & 6.6 \\
\hline La Feliciana & Mar $2 \mathrm{ab}$ & $110 \mathrm{a}$ & June $28 \mathrm{a}$ & 3.8 & $5.8 \mathrm{a}$ & $6.4 \mathrm{bc}$ & $6.8 \mathrm{a}$ & $7.0 \mathrm{ab}$ & $7.2 \mathrm{ab}$ & $5.6 \mathrm{c}$ & 0.5 & $6.3 \mathrm{~b}$ & 7.0 \\
\hline
\end{tabular}

${ }^{2}$ Full bloom $=60 \%$ to $80 \%$ flowers open, FDP = fruit development period, number of days from full bloom to ripe, Ripe date = date when $20 \%$ of the fruits are at the firm ripe stage. ${ }^{y}$ Crop rating 0 to $9,0=$ no crop, $3=60 \%$ full crop, $5=$ full commercial crop, 1 fruit every $20 \mathrm{~cm}, 7=1$ fruit per $10 \mathrm{~cm}, 9=1$ fruit per $5 \mathrm{~cm}$ of fruiting wood

'Size ratings of diameter $(\mathrm{mm}) 0$ to $9,4=51$ to $57,5=58-64,6=65$ to $70,7=71$ to 76

Rating scale 0 to $9 ; 0$ to $4=$ unacceptable, $5=$ marginal, $6=$ good, $7=$ very good, 8 to $9=$ excellent for commercial use. All ratings done by author under field conditions.

Rated on percent basis. $0=$ no red, $5=50 \%$ flesh with red, $9=90 \%$ or more with red.

"Mean separation within columns by Duncan's multiple range test at the 5\% level. Items with the same letter are not significantly different. No letters within a column indicates no significant differences

\section{Literature Cited}

Andrews, C.P., W.B. Sherman, and P.M. Lyrene. 1979 'Flordaking' Peach. HortScience 14:81-82.

Anon., 1995. RHS Colour Chart. The Royal Hort. Soc., London.

Byrne, D.H. and J.S. Kamas. 1984. 'Texstar' Peach.
HortScience 19:453-454.

Byrne, D.H., and T.A. Bacon. 1991. 'TexRoyal', a medium-chilling peach. HortScience 26:13381340

Okie, W.R. and C.C. Reilly. 1987. 'Juneprince' and 'Fireprince' peaches. HortScience 22:325326. 